\title{
IMPROVEMENT OF FINANCIAL ACTIVITIES OF HOTELS THROUGH INNOVATIVE TECHNOLOGIES
}

\author{
Maria V. Petrovskaya \\ Faculty of Economics \\ RUDN University \\ Moscow, Russia \\ Petrovskaya_mv@rudn.university
}

\author{
Elena M Grigorieva \\ Faculty of Economics \\ RUDN University \\ Moscow, Russia \\ Grigorieva_em@rudn.university
}

\author{
Natalia A. Zaitseva \\ Faculty of Hotel and Restaurant, Tourism and Sports Industry \\ Plekhanov Russian University of Economics \\ Moscow, Russia \\ Zaitseva-itig@mail.ru
}

\begin{abstract}
The introduction of innovations in the hotel business in modern conditions is no longer a competitive advantage, but a prerequisite for a financially sustainable development of a hotel company. At the same time, the effective development of innovative activities in hotels is impossible without the introduction of various forms of integration, both at the level of individual hotel enterprises and networks, and at the regional level. In this regard, the authors of the article set the goal to determine what kinds of innovations are most promising and to determine measures to improve the financial activities of hotels through the introduction of innovative technologies. To carry out the research, the authors of the article used methods of content analysis, factor analysis, data systematization, the method of peer review, a method for negotiating expert assessments, and other scientific approaches that allow a comprehensive study of the problem under review and analytical reviews of professional communities and experts. The article substantiates the main problems that have a negative impact on the development of innovative activities in hotels. Also author's classifications of types of innovations used in the hotel business were developed, and examples of such innovations are given. The materials of the article can be of interest to scientists engaged in research on issues of innovation in hotels, as well as the heads of hotels and offices for the development of hotel business in the regions.
\end{abstract}

Keywords - innovations, financial activity, hotels, performance indicators

\section{INTRODUCTION}

In modern conditions of transition to the digital economy, the introduction of innovations is no longer a competitive advantage, but a necessary condition for the sustainable development of almost any business.

In the scientific and normative literature there are different approaches to defining the essence of the concept of "innovation". In Federal Law No. 254-FL of July 21, 2011, innovations are considered as a new or significantly improved product (product, service) or process, a new sales method or a new organizational method in business practice, workplace organization or in external relations. At the same time Yu.A. Arutyunov (2011) [1] notes that innovations cannot be considered as any innovation, but as the only one that commercializes and seriously increases the effectiveness of the current system.

The main scientific approaches to the definition of the essence of the concept of "Innovation in the hotel business." will be considered next. J. Mattson (2005) [9] defines innovations in the hospitality industry as a more "soft" kind of innovation, based on abilities and interorganizational cooperation. There is a narrower approach to determining the essence of innovation in hotels. For example, E. Martínez-Ros \& F. Orfila-Sintes (2009) [8], defining innovation in the hospitality industry, focus primarily on the extensive use of numerous computer technologies and other software solutions.

F. Gallouj (2002) [6], noting the peculiarities of innovations in the hotel business, points to their greater social and organizational component than in the production sectors of the economy. Summarizing the approaches to the classification of types of innovations in the hospitality industry (De Lurdes Calisto, 2015 [5]; Lien, 2015 [10]; W.-H. Chiu, Y.-T. Lai, H.R. Chi, 2017 [4]; L. Vagen, 2001 [13]; I.V. Zorin, 2003) [15], available in scientific research, the authors of the article distinguished the following classification characteristics (Table 1). 
TABLE 1. CLASSIFICATION OF TYPES OF INNOVATION IN HOTEL ACTIVITIES AND THEIR FEATURES

\begin{tabular}{|c|c|}
\hline Classification feature & Types and features of innovation in hotels \\
\hline $\begin{array}{l}\text { The source of the idea, } \\
\text { on the basis of which } \\
\text { the innovation was } \\
\text { developed }\end{array}$ & $\begin{array}{l}\text { Needs of guests, partners (existing and potential) } \\
\text { Discoveries, inventions having an interbranch } \\
\text { nature }\end{array}$ \\
\hline $\begin{array}{l}\text { The kind of } \\
\text { innovation, the scope } \\
\text { of its application (what } \\
\text { is the innovation } \\
\text { related to) }\end{array}$ & $\begin{array}{l}\text { Infrastructure of hotel business } \\
\text { Hotel product } \\
\text { The ways and means of promoting the hotel product }\end{array}$ \\
\hline Investment content & $\begin{array}{l}\text { Non-capital-intensive (not requiring significant } \\
\text { financial investments both in the hotel product } \\
\text { itself, and in its promotion, with a payback period } \\
\text { of up to } 1 \text { year) } \\
\text { Small capital-intensive (as a rule it improves the } \\
\text { innovation, assuming a payback period of } \\
\text { investments in their development and } \\
\text { commercialization from } 1 \text { to } 3 \text { years) } \\
\text { Capital-intensive (the payback period of } \\
\text { investments in their development and } \\
\text { commercialization, as a rule, is from } 3 \text { years) }\end{array}$ \\
\hline Degree of novelty & $\begin{array}{l}\text { Enhancing (making small changes in the existing } \\
\text { hotel product, the technology of its formation and } \\
\text { promotion) } \\
\text { Breakthrough (significant changes in the hotel } \\
\text { business, for example, fully robotic hotels) }\end{array}$ \\
\hline $\begin{array}{l}\text { Breadth of impact, } \\
\text { scale }\end{array}$ & $\begin{array}{l}\text { Local (within the framework of a particular hotel } \\
\text { chain (national or international) } \\
\text { Global (covering a large number of networked and } \\
\text { independent hotels in many countries) }\end{array}$ \\
\hline
\end{tabular}

The conducted research made it possible to identify three main problems of introducing innovations in hotels related to the financial aspects of their activities (Table 2).

TABLE 2. THE MAIN PROBLEMS OF INTRODUCING INNOVATIONS IN HOTELS RELATED TO THE FINANCIAL ASPECTS OF THEIR ACTIVITIES

\begin{tabular}{|c|c|}
\hline \multicolumn{2}{|r|}{ The main problems } \\
\hline \multirow{2}{*}{$\begin{array}{l}\text { 1. Problems associated } \\
\text { with the development } \\
\text { of innovative hotel } \\
\text { products }\end{array}$} & $\begin{array}{l}\text { 1.1. The lack of research structures involved in the } \\
\text { development of innovative hotel products. }\end{array}$ \\
\hline & $\begin{array}{l}\text { 1.2. Closeness of information about the innovations } \\
\text { being developed and already implemented in hotels }\end{array}$ \\
\hline \multirow{2}{*}{$\begin{array}{l}\text { 2. Problems associated } \\
\text { with the low level of } \\
\text { qualification of hotel } \\
\text { management }\end{array}$} & $\begin{array}{l}\text { 2.1. Many hotel managers were not trained in } \\
\text { innovation management programs }\end{array}$ \\
\hline & $\begin{array}{l}\text { 2.2. Inadequate attention in the educational plans for } \\
\text { training specialists in the field of hotel business on } \\
\text { issues of innovation management }\end{array}$ \\
\hline \multirow{2}{*}{$\begin{array}{l}\text { 3. Problems associated } \\
\text { with the lack of } \\
\text { financial resources } \\
\text { necessary for the } \\
\text { development and } \\
\text { implementation of } \\
\text { innovation in hotels }\end{array}$} & $\begin{array}{l}\text { 3.1. Independent hotels have limited financial } \\
\text { resources, which are primarily directed not at the } \\
\text { solution of current problems at the expense of } \\
\text { strategic innovative projects }\end{array}$ \\
\hline & $\begin{array}{l}\text { 3.2. Hotel chains, having innovative budgets } \\
\text { approved at the central office level, as a rule, do not } \\
\text { have the right to promptly change them, if there is a } \\
\text { need for it. }\end{array}$ \\
\hline
\end{tabular}

As can be seen from the data in Figure 1, most of the problems of introducing innovations in hotels are associated with the low efficiency of innovative management, which results for the most part in reactive innovation policies, large amounts of errors and low effectiveness in introducing innovations (for example, the introduction of innovations in resort hotels by the example of business hotels, i.e. which are not relevant to the target audience, hotels which are oriented to recreation and relaxation)

\section{PROBlem STATEMENT}

As can be seen from the above material, due to the peculiarities of the hotel business, innovation activity is characterized by instability and a greater influence of strategic factors on the strategic development of hotels than in the industrial sector. The uneven development of the hotel business in different regions, the specific training of personnel for this area - all this is reflected in the process of introducing innovations in hotels, and, as a result, not the results of financial activities (Barancheev, 2014) [2]. Therefore, it is so important to consider this problem in a complex - both at the level of individual companies and at the regional level.

\section{RESERCH QUESTIONS}

Based on the results of the research conducted earlier by the authors of the article, several issues that have not been adequately studied in the work of both the Russian and international scientific community have been identified so far. First of all, it is necessary to carry the following to such questions:

- clarification of the essence of innovation in hotels and its features;

- substantiation of the problems hampering the development of innovative activity in the hotel business - both in independent hotels and in hotel chains;

- definition of methods and indicators of an estimation of efficiency of innovative activity in hotels and their influence on the total indicators characterizing financial activity of hotels;

- development of practical measures for the creation of Centers for Support of Innovative Activity in the Hotel Business at the Regional Level.

This study is directed to solve the above issues.

\section{PURPOSE OF THE STUDY}

The purpose of this study was to identify the most promising types of innovation and develop measures to improve the financial performance of hotels through the introduction of innovative technologies. In addition, it is important to determine methods for assessing the effectiveness of innovation in the hospitality industry, as well as indicators that characterize the financial performance, taking into account the specifics of hotels

\section{RESEARCH METHODS}

The methodological basis of this study was the work in the field of financial activities of hotels due to the introduction of innovative technologies. To analyze the current situation and trends in the development of innovative activities in Russia and 
in the world, the authors of the article used methods of content analysis, factor analysis, systematization of data, the method of expert assessments, the method of agreeing expert assessments, and other scientific approaches that allow a comprehensive study of the problem, reviews of professional communities and experts.

\section{FINDINGS}

A. Influence of macroeconomic tendencies in the financial and banking sector on the introduction of innovative technologies.

The study of the dynamics of the use of bank cards in the Russian Federation rendered that if in 2012 the ratio of cash withdrawal operations and the use of bank cards for non-cash payment of goods and services was the same - for 2.8 billion transactions, then in 2015 the ratio was already $27.5 / 72.5$ (3.3 and 8.7 billion respectively). By the end of 2017, this trend only increased - the ratio was 16.3 / 83.7 (3.3 and 17.0 billion transactions, respectively) (Table 3 ).

TABLE 3. DYNAMICS OF THE NUMBER OF TRANSACTIONS WITH BANK CARDS FOR THE PERIOD FROM 2012 TO 2017 IN THE RUSSIAN FEDERATION, BILLIONS OF TRANSACTIONS

\begin{tabular}{|l|c|c|c|c|}
\hline \multirow{3}{*}{ Years } & \multicolumn{2}{|c|}{$\begin{array}{c}\text { number of cash withdrawal } \\
\text { operations }\end{array}$} & \multicolumn{2}{|c|}{$\begin{array}{c}\text { number of transactions for } \\
\text { non-cash payment for goods } \\
\text { and services }\end{array}$} \\
\cline { 2 - 5 } & $\begin{array}{c}\text { share in the } \\
\text { total number } \\
\text { of } \\
\text { transactions }\end{array}$ & $\begin{array}{c}\text { share in the } \\
\text { total number } \\
\text { of } \\
\text { transactions } \\
\text { with bank } \\
\text { cards }\end{array}$ & $\begin{array}{c}\text { transactions } \\
\text { trillions of } \\
\text { transactions } \\
\text { with bank } \\
\text { cards }\end{array}$ \\
\hline 2012 & 2,8 & 2,8 & 50,0 & 50,0 \\
\hline 2013 & 3,2 & 4,2 & 43,2 & 56,8 \\
\hline 2014 & 3,3 & 6,1 & 35,1 & 64,9 \\
\hline 2015 & 3,3 & 8,7 & 27,5 & 72,5 \\
\hline 2016 & 3,4 & 12,3 & 21,7 & 78,3 \\
\hline 2017 & 3,3 & 17,0 & 16,3 & 83,7 \\
\hline
\end{tabular}

The interest of the population in the use of bank cards for non-cash settlements is explained not only by their simplicity and security. This is also facilitated by various incentive programs, developed by banks, from schemes with bonuses and to a variety of cashback options. Currently, bank cards are accepted in Russia to pay for services and goods not only in large retail chains, but also in small stores. In addition, small business and individual entrepreneurs connected to this, understanding that without this service their services become less competitive.

In the Russian hotel business, the growth trend of non-cash transactions generally corresponds to the all-Russian one. Moreover, as experts of the hotel business predict, in 2018, the transition of hotels to the use of their own mobile applications will continue. So, AccorHotels, which plans to become a leader in this direction, signed an agreement with the supplier of First Data payment solutions in November 2017 to facilitate transactions for online booking for customers. The first projects will be implemented in the UK, Germany and France. After testing, this experience will be broadcast in other countries during 2018-2019.
People most actively use the service of on-line booking, including through mobile applications - participants in loyalty programs developed by hotels. Therefore, according to the results of Oracle research, about $79 \%$ of participants in loyalty programs book hotels directly (http://hotelier.pro/news/item/3016-sochi).

Another trend in the introduction of innovations in the hotel business with a view to improving financial activity is the development of own messengers which are used within the hotel chains. So Marriott company launches its own mobile service under the mPlaces brand, which will be based on the existing network of beacons LocalPerks. Such a system will allow, among other things, to send guests personalized marketing messages about services in the hotel and various promotions.

\section{B. Establishment of the Centers for innovative development of hospitality as a promising direction of improving the financial activity of hotels by introducing innovative technologies}

Based on the results of the study, several areas for improving the financial performance of hotels can be identified through the introduction of innovative technologies. First of all, this is the use by hotels of various forms of integration with other participants of the innovation infrastructure. If we consider this process at the regional level, then it can be such forms of cooperation as entrepreneurial networks and clusters. The creation of such structures presupposes the existence of a management company. This company can have a different level of authority - from the maximum wide management to individual coordination or monitoring functions.

In addition, organizations that perform the functions of the Center for innovative hospitality development can be established at the regional level. In this Center, young entrepreneurs could get help in organizing a start-up and use the services of an information and analytical service. In such a Center it is advisable to have its own press service, thanks to which small and medium-sized enterprises engaged in innovation can gain greater fame among potential users of their services.

Also, the center will offer services in the selection of innovations for a ready-made business. There are many scientists who have innovative experience, but for one reason or another do not create their own business. Thus, these developments remain unused and not realized, although they could bring real benefits to business. "Center for innovative development of hospitality" will be able to accumulate these ideas by acquiring rights to innovate with the inventor, or create conditions for effective interaction between inventors and owners of the hotel business, real and potential investors. Thanks to this, it will be possible to involve those segments of the population that are not usually involved in creating an innovative infrastructure.

In addition, such a center can accumulate applications of owners of the hotel business to develop innovations, the need for which they identify in the process of analyzing the satisfaction of guests and partners with the work with a particular independent hotel or hotel chain. 
Consumers of services of the Center can be different organizations and individuals. It is assumed that the main consumers will be investors and owners of the hotel business. They can contact the Center with a technical assignment for the innovation they need. Such an approach will help the subjects of innovative entrepreneurship to have a constant volume of work and ideas for start-ups, meeting the demand for innovative products, services and technologies existing in the hotel business

\section{Evaluation of the effectiveness of innovation financing}

To assess the effectiveness of financing innovative activity, the approach proposed by K.A. Barmuta (2010) [3], based on the use of the "cost-time" function could be used. Within the framework of this approach, the correlation equation is applied, the parameters of which vary depending on many factors that characterize both the innovation itself and the conditions for its implementation, for example, in an independent hotel or hotel chain:

$$
C=v * e^{\frac{\phi}{t / \alpha-1}}
$$

where $\mathrm{C}$ - are expected innovative costs; $\mathrm{t}$ - is the expected time; $v, \alpha, \varphi$ - parameters that change from innovation to innovation (are determined on the basis of expert assessments of the leaders of innovation projects).

In this case, the elasticity of costs over time can be represented by the expression:

$$
\ln C=\ln v+\phi\left(\frac{t}{\alpha}-1\right)^{-1},
$$

By converting the above two formulas, we can determine the value of $t$, which satisfies the maximization of profit condition. Presented models of the ratio of cost and time costs in the process of creating innovations can be effectively used in the process of managing innovation activities of industrial firms, on the assumption of an effective system of accounting for innovation costs for the main stages of innovation realization (A.A. Zabolotko, 2013) [14].

In addition, the introduction of innovations in hotels contributes to the growth of the number of rooms (, which results in an improvement in the values of financial performance indicators. In the hotel business, such indicators include (M.V. Petrovskaya, A.A. Larionova, N.A. Zaitseva, N.V. Bondarchuk, E.M. Grigorieva, 2016 [11]; M.V. Petrovskaya, N.A. Zaitseva, N.V. Bondarchuk, E.M. Grigorieva, L.S. Vasilieva, 2016 [12]):

- $\quad$ Revenue per Available Room (RevPAR);

- Average Room Rate (ARR);

- Rooms Yield;

- Actual Rooms Yield;

- Average Check Price;

- Food Cost Percentage;

- Labor Cost Percentage;

- Solvency and financial sustainability (Solvency Ratio, Debt-Equity Ratio, Number of Times Interest Earned, Fixed Charge Coverage Ratio, etc.);
- $\quad$ Profitability (Profit Margin Ratio, Return on Owner's Equity Ratio, Return on Assets Ratio, Return on Fixed Assets Ratio, etc.).

\section{CONCLUSION}

In general, based on the results of a study conducted by the authors of the article, it can be concluded that the introduction of innovations in hotels has a specific nature. In addition, there is a number of problems that adversely affect the effectiveness of innovation in hotels.

Within the framework of this article, it is justified that the decision to improve the financial activities of hotels through the introduction of innovations is most effective if we create regional Centers that promote the development of innovative activities in the hotel business.

To assess the effectiveness of improving the financial performance of hotels due to the introduction of innovations, the authors of the article proposed methods and indicators, the use of which by hotel managers will allow them to quickly monitor the effectiveness of this activity

\section{References}

[1] Yu.A. Arutyunov, «Innovative development as an economic category», Creative Economy, vol. 5 (2), pp 8-12, 2011.

[2] V.P. Barancheev, The management of innovation: a textbook for bachelors -2 ed., Pererab. And add. Moscow, Publishing House Yurayt, 2014.

[3] K.A. Barmuta, "Managing the effective development of industrial enterprises in terms of mastering innovation: theory, methodology, practice", Thesis for the degree of Doctor of Economic Sciences. Moscow. Moscow State Regional University, 2010.

[4] W.H. Chiu, Y.T. Lai, H.R. Chi, «Service innovation in the lodging industry: A perspective of customer value». 14th International Conference on Services Systems and Services Management, ICSSSM 2017 Proceedings, 7996226, 2017.

[5] M.De Lurdes Calisto, «How some hr management practices may hinder innovation: The case of the hotel industry». Proceedings of the European Conference on Innovation and Entrepreneurship, ECIE. January, pp. 113$120,2015$.

[6] F. Gallouj, "Innovation in the Service Economy: The New Wealth of Nations", Edward Elgar Publishing Limited, Cheltenham, 2002.

[7] Ya.V. Grebenkova, «Innovations in the hotel business». The journal "Modern High Technologies", vol. 10-2, pp. 247, 2013.

[8] E. Martínez-Ros, F. Orfila-Sintes, «Innovation activity in the hotel industry. Technovation», vol. 29(9), pp. 632-641, 2009.

[9] J. Mattson, "Innovation Systems in Tourism: The Roles of Attractors and Scene-Takers", Industry and Innovation, pp. 357-381, 2005.

[10] E. Ng, C.-Y. Lien, Impact of social media in service innovations: An empirical study on the Australian hotel industry (Book Chapter), 2015.

[11] M.V. Petrovskaya, A.A. Larionova, N.A. Zaitseva, N.V. Bondarchuk, E.M. Grigorieva, «Methodical approaches to determine the level of risk associated with the formation of the capital structure in conditions of unsteady economy», International Journal of Environmental \& Science Education, vol.11 (11), pp. 4005-4014, 2016

[12] M.V. Petrovskaya, N.A.Zaitseva, N.V. Bondarchuk, E.M.Grigorieva, L.S. Vasilieva, «Scientific methodological basis of the risk management implementation for companies' capital structure optimization», IEJME Mathematics Education, vol.11 (7), pp. 2571-2580, 2016.

[13] L.Vagen, The hotel business. Rostov on the Don, Phoenix, 2001 
[14] A.A. Zabolotko, Innovative development of the economy: concept, problems and solutions. State and municipal management. Scientific notes SKAGS, vol. 3, pp. 192-196, 2013

[15] I.V. Zorin, Encyclopedia of tourism. Moscow: Finance and Statistics, 2003 